\title{
Thrombin-induced platelet aggregation, phosphoinositide metabolism and protein phosphorylation in NIDDM patients treated by diet, sulphonylurea or insulin
}

\author{
T. Ishizuka, O. Taniguchi, M. Yamamoto, K. Kajita, T. Nagashima, N. Takeda, H. Inouye, K. Yasuda, K. Miura \\ The Third Department of Internal Medicine, Gifu University School of Medicine, Tsukasamachi, Gifu, Japan
}

\begin{abstract}
Summary We studied thrombin-induced metabolism of phosphoinositide, protein phosphorylation and platelet aggregation in platelets from 32 NIDDM patients and 12 control subjects. To clarify the effect of diet, sulphonylureas, or insulin treatment, the subjects were divided into three groups based on the type of treatment. Thrombin-induced platelet aggregation was measured with an aggregometer. Low-dose thrombin $(0.25 \mathrm{U} / \mathrm{ml})$-stimulated platelet aggregation in diabetic patients was significantly increased compared with the control subjects. Platelet aggregation in the sulphonylurea and insulin groups was significantly lower than in the diet group. On the other hand, in platelets incubated with $\left[{ }^{32} \mathrm{P}\right]$ orthophosphate, thrombin-induced incorporation of ${ }^{32} \mathrm{P}$ radioactivity into phosphatidic acid (PA) was significantly lower in the sulphonylurea and
\end{abstract}

insulin groups than in the diet group. Thrombin-induced incorporation of $\left[{ }^{32} \mathrm{P}\right]$ radioactivity into phosphatidylinositol (PIP) for $10 \mathrm{~s}$ was significantly higher in the sulphonylurea group than in the diet group. There were no differences in thrombin-induced $47 \mathrm{kDa}$ protein phosphorylation between platelets from the diet, sulphonylurea, or insulin groups. These results suggest that sulphonylureas and insulin induce suppression of thrombin-induced activation of phospholipase C, which mediates hydrolysis of PIP and $\mathrm{PIP}_{2}$ and production of $\mathrm{PA}$, which leads to inhibition of platelet aggregation. [Diabetologia (1994) 37: 632-638]

Key words Platelet aggregation, phosphoinositides, thrombin, treatment, protein phosphorylation, microangiopathy.
Functions of platelets such as aggregation, serotonin and ADP secretion, and thromboxane $\mathrm{A}_{2}$ production are mediated by mechanisms of signal transduction. Thrombin causes hydrolysis of $\mathrm{PIP}_{2}$ by phospholipase $\mathrm{C}$ with concomitant formation of diacylglycerol

Received: 12 July 1993

and in final revised form: 17 January 1994

Corresponding author: Dr. T. Ishizuka, The Third Department of Internal Medicine, Gifu University School of Medicine, Tsukasamachi 40, Gifu 500, Japan

Abbreviations: NIDDM, Non-insulin-dependent diabetes mellitus; IDDM, insulin-dependent diabetes mellitus; PA, phosphatidic acid; PI, phosphatidylinositol; PIP, phosphatidylinositol 4monophosphate; $\mathrm{PIP}_{2}$, phosphatidylinositol 4,5-bisphosphate; TPA, 12-O-tetradecanoylphorbol-13-actate; $\mathbf{I P}_{3}$, inositol 1,4,5trisphophate; E/I, expiration/inspiration; HPLTC, high performance thin layer chromatography and $\mathrm{IP}_{3}$ which induces the rapid release of $\mathrm{Ca}^{2+}$ from a dense tubular system [1-5], and stimulates phospholipase $A_{2}$ to release arachidonic acid. Diacylglycerol is known to activate protein kinase $\mathrm{C}[6,7]$, and is effectively phosphorylated to $\mathrm{PA}$, which can then be redirected to PI through cytidine diphosphate-diacylglycerol as shown in Figure 1. On the other hand, arachidonic acid is oxygenated to produce thromboxane $A_{2}$ [8].

Platelet aggregating function in diabetic patients is increased compared with healthy subjects $[9,10]$. Moreover, enhanced arachidonic acid release and thromboxane production have been reported in platelets from NIDDM patients $[11,12]$. Recently there have been reports [13-15] focusing on thrombin-induced changes in phosphoinositide metabolism in diabetic patients. Decreased platelet phosphoinositide turnover and enhanced platelet activation in IDDM patients have also been reported [13]. On the other 
hand, an increased platelet phophoinositide turnover has been observed together with an enhanced platelet aggregating function in NIDDM patients who are being treated with sulphonylureas or insulin [14]. We have also reported that the breakdown of phosphoinositides increases in NIDDM patients with retinopathy and decreases in NIDDM patients with macroangiopathy [15]. However, the patients in these studies were undergoing various diabetic treatments, thereby complicating interpretation of the results of platelet aggregating function and thrombin-induced alteration of phosphoinositide.

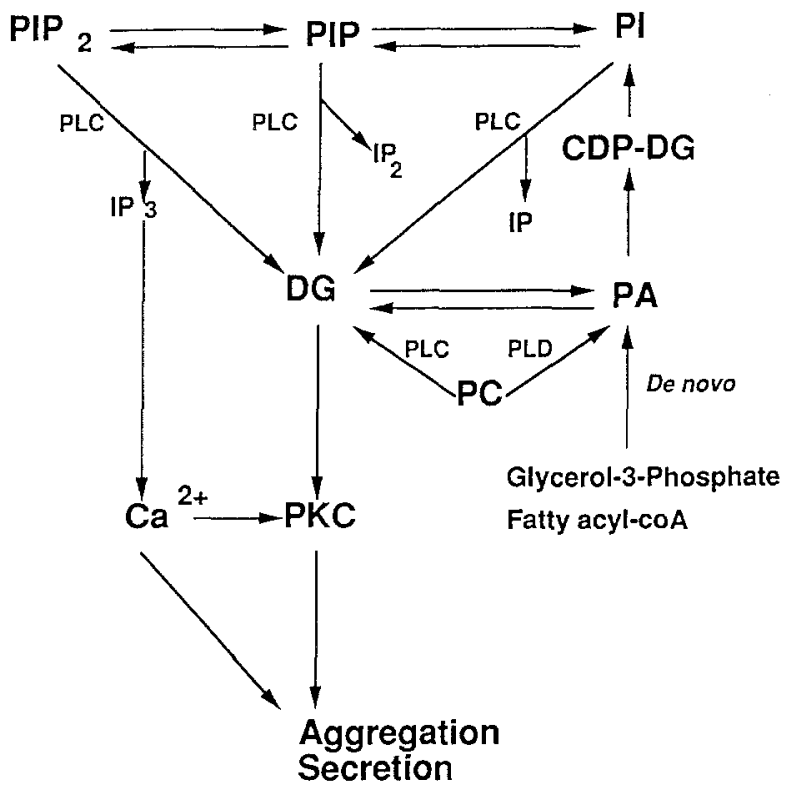

Fig.1. Simplified polyphosphatidylinositol cycles. The PI cycle has PI and DG as common metabolites, and the steps are believed to be controlled by thrombin stimulation. The following abbreviations are used: PI, phosphatidylinositol; PIP, phosphatidylinositol-4-monophosphate; $\mathrm{PIP}_{2}$, phosphatidylinositol-4,5bisphosphate; PA, phosphatidic acid; PC, phosphatidylcholine; DG, diacylglycerol; $\mathrm{IP}_{3}$, inositol 1,4,5-triphosphate; CDP-DG, cytidine diphosphate diacylglycerol; PLC, phospholipase C; PLD, phospholipase D; PKC, protein kinase C
In this study, we have compared thrombin-induced platelet aggregation, phosphoinositide metabolism and protein phosphorylation in NIDDM patients treated by diet, sulphonylurea or insulin.

\section{Subjects and methods}

Subjects. The NIDDM patient group comprised 18 men and 14 women, ranging in age from 40 to 67 years. They were admitted to The Third Department of Internal Medicine, Gifu University Hospital during 1991-1992, and were not being treated with any medication which could affect platelet aggregation. The control subjects had no history of diabetes or any other serious medical condition. All subjects gave their informed consent for participation and the study was approved by the regional Ethics Committee. The diagnosis of diabetes was confirmed according to the criteria recommended by the World Health Organization Expert Committee on Diabetes Mellitus. Glucagonstimulated C-peptide secretion was routinely performed on the diabetic patients to ascertain endogenous insulin secretion. The NIDDM patients were divided into three groups as shown in Table 1: those treated with diet alone ( $n=8$, diet group); those treated with diet plus sulphonylureas ( $n=12$, sulphonylurea group); and those treated with diet plus insulin ( $n=12$, insulin group). In the diet group, two patients had been diagnosed with diabetic retinopathy (one with background retinopathy and the other proliferative retinopathy), two had been diagnosed with overt nephropathy (microalbuminuria more than $200 \mu \mathrm{g} / \mathrm{min}$ ), and, two with macroangiopathy (angina pectoris and aortic calcification, respectively). In the sulphonylurea group, seven patients had been diagnosed with diabetic retinopathy (two with background, one with preproliferative, and four with proliferative retinopathy, respectively), three had been diagnosed with neuropathy with weak patellar and Achilles tendon reflexes, decreased motor nerve conduction velocity, and abnormal expiration/inspiration ratio [16] which was assessed by measuring the ratio of the longest to the shortest $\mathrm{R}-\mathrm{R}$ interval during deep breathing. Three patients had been diagnosed with nephropathy (proteinuria), and three with macroangiopathy (one with angina pectoris, and two with aortic calcification, respectively). In the insulin group, 10 patients had been diagnosed with diabetic retinopathy (one with background, one with preproliferative, and eight with proliferative retinopathy), 10 had been diagnosed with nephropathy with proteinuria, seven with neuropathy with abnormal tendon reflex, motor nerve conduc-

Table 1. Clinical and biochemical characteristics of study subjects

\begin{tabular}{|c|c|c|c|c|c|c|}
\hline Group & $n$ & BMI & Age (years) & $\begin{array}{l}\text { Duration of } \\
\text { diabetes (years) }\end{array}$ & $\mathrm{FBG}(\mathrm{mmol} / \mathrm{l})$ & $\mathrm{HbA}_{\mathrm{lc}}(\%)$ \\
\hline Control & 12 & $21.5 \pm 2.0$ & $45 \pm 20$ & 1 & $4.8 \pm 0.3$ & $5.0 \pm 0.6$ \\
\hline Diet & 8 & $26.5 \pm 5.3$ & $53 \pm 13$ & $5.5 \pm 2.9$ & $7.5 \pm 1.2$ & $7.5 \pm 1.1$ \\
\hline \multirow[t]{2}{*}{ Insulin } & 12 & $23.6 \pm 2.8$ & $55 \pm 12$ & $14.8 \pm 10^{\mathrm{a}}$ & $9.6 \pm 3.4$ & $9.5 \pm 1.7$ \\
\hline & $\begin{array}{l}\text { Cholesterol } \\
(\mathrm{mmol} / \mathrm{l})\end{array}$ & $\begin{array}{l}\mathrm{TG} \\
(\mathrm{mmol} / \mathrm{l})\end{array}$ & $\begin{array}{l}\text { Retino- } \\
\text { pathy }(\%)\end{array}$ & $\begin{array}{l}\text { Neuro- } \\
\text { pathy (\%) }\end{array}$ & $\begin{array}{l}\text { Nephro- } \\
\text { pathy (\%) }\end{array}$ & $\begin{array}{l}\text { Macroangio- } \\
\text { pathy }(\%)\end{array}$ \\
\hline Diet & $5.17 \pm 0.72$ & $2.42 \pm 0.47$ & 25 & 0 & 25 & 25 \\
\hline Sulphonylurea & $4.65 \pm 0.57$ & $1.51 \pm 0.65$ & 58.3 & 33.3 & 41.7 & 25 \\
\hline Insulin & $4.86 \pm 0.67$ & $1.72 \pm 0.54$ & $92.3^{a}$ & 53.8 & $84.6^{a}$ & 50 \\
\hline
\end{tabular}

Values are given as mean \pm SD.

${ }^{a} p<0.01$, insulin or sulphonylurea group vs diet group; FBG, fasting blood glucose; TG, triglycerides 


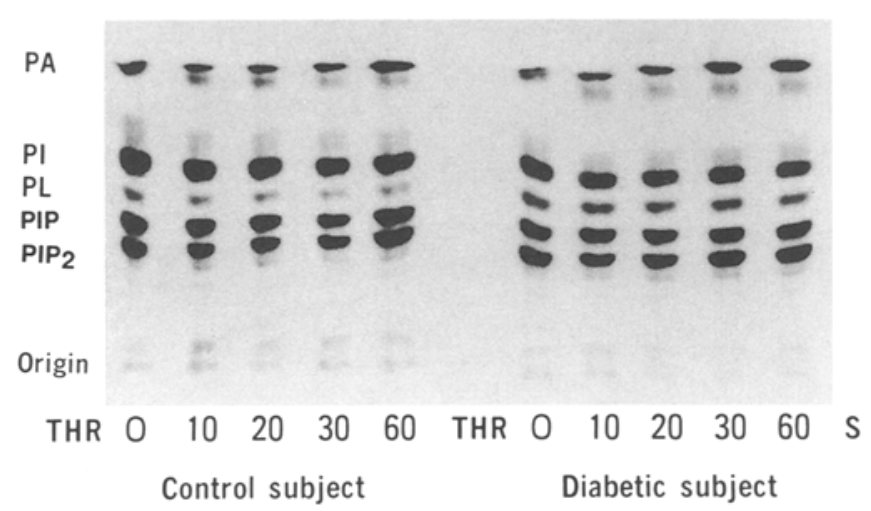

Fig. 2. Thrombin $(1 \mathrm{U} / \mathrm{ml})$-stimulated phosphoinositide metabolism in platelets from a representative diabetic and control subject. Phosphatidylinositol-4,5-bisphosphate $\left(\mathbf{P I P}_{2}\right)$ was hydrolysed at $10 \mathrm{~s}$ after stimulation with thrombin in platelets from each diabetic and control subject. PL, phospholipid

tion velocity, and expiration/inspiration ratio, and six patients with macroangiopathy with aortic calcification.

Preparation of $~^{32} \mathrm{P}$-labelled human platelets: Fresh blood was obtained from the control subjects and diabetic patients between 07.00 and 09.00 hours before breakfast and before each treatment, and then centrifuged at $164 \times g$ for $10 \mathrm{~min}$ as described previously [15]. The resulting supernatant (platelet-rich plasma) was centrifuged at $800 \times \mathrm{g}$ for $10 \mathrm{~min}$, washed, resuspended in buffer I $(15.4 \mathrm{mmol} / \mathrm{l}$ Tris, $140 \mathrm{mmol} / \mathrm{l} \mathrm{NaCl}$ and $5.6 \mathrm{mmol} / \mathrm{h} \mathrm{glu}$ cose, $\mathrm{pH} 7.4$ ), and incubated with $\left[{ }^{32} \mathrm{P}\right]$ orthophosphate $(200 \mu \mathrm{Ci})$ for $90 \mathrm{~min}$ at $37^{\circ} \mathrm{C}$. The labelled platelets were washed and resuspended in buffer I containing $1 \mathrm{mmol} / \mathrm{l} \mathrm{CaCl}_{2}$ at a final concentration of $10^{9} / \mathrm{ml}$.

Lipid analysis: After the platelet suspension ( $490 \mu \mathrm{l})$ was incubated with $1 \mathrm{U} / \mathrm{ml}$ thrombin, $2 \mathrm{ml}$ of chloroform $/ \mathrm{methanol} / \mathrm{HCl}$ $(20: 40: 1, \mathrm{v} / \mathrm{v} / \mathrm{v})[17]$ was added and lipid was then extracted by a modification of the Bligh-Dyer method [18]. Briefly, the resultant mixture was supplemented with $0.5 \mathrm{ml}$ chloroform, mixed, and centrifuged at $2500 \mathrm{rev} / \mathrm{min}$ for $5 \mathrm{~min}$. The lower phase was collected and $0.5 \mathrm{ml}$ of $0.2 \mathrm{~mol} / 1 \mathrm{KCl}-5 \mathrm{mmol} / \mathrm{l}$ EDTA mixture was added. The phases were separated by centrifugation, and the lower phase was collected and dried under nitrogen. The phosphoinositides were separated on HPTLC plates, and impregnated with $1 \%$ potassium oxalate in a solvent system of chloroform/acetone/methanol/acetic acid/water (40:15:13:12: $8, \mathrm{v} / \mathrm{v} / \mathrm{v} / \mathrm{v} / \mathrm{v})$ [19]. The areas corresponding to individual lipids, identified by co-migration with authentic standards as indicated in Figure 2, were scraped into vials and radioactivity was determined by a scintillation counter with toluene/ Triton X-100/ water/2,2'-p-phenylene-bis(5-phenyloxazole)/2,5 diphenyloxazole ( $800 \mathrm{ml}: 200 \mathrm{ml}: 50 \mathrm{ml}: 0.24 \mathrm{~g}: 3.3 \mathrm{~g})$. The rate of radioactivity of each phospholipid was calculated.

Platelet aggregation: Platelet aggregation was achieved by Born's turbidimetric method [20] with an aggregometer (NBS Hema Tracer 801; NBS Niko Bioscience Inc., Tokyo, Japan). Briefly, $100 \mu$ lof platelet-rich plasma was stirred magnetically at $1100 \mathrm{rev} /$ $\min , 37^{\circ} \mathrm{C}$. After a 1 -minincubation, $0.25,0.3,0.5$ or $1 \mathrm{U} / \mathrm{ml}$ bovine thrombin was added, and the change in light transmission was recorded for $7 \mathrm{~min}$. The maximum aggregation was determined as the peak light transmission after addition of thrombin.

Phosphorylation of $47 \mathrm{kDa}$ protein: ${ }^{32} \mathbf{P}$-labelled platelets were stimulated with $1 \mathrm{U} / \mathrm{ml}$ thrombin for $1 \mathrm{~min}$ or $10^{-6} \mathrm{~mol} / 1 \mathrm{TPA}$ for
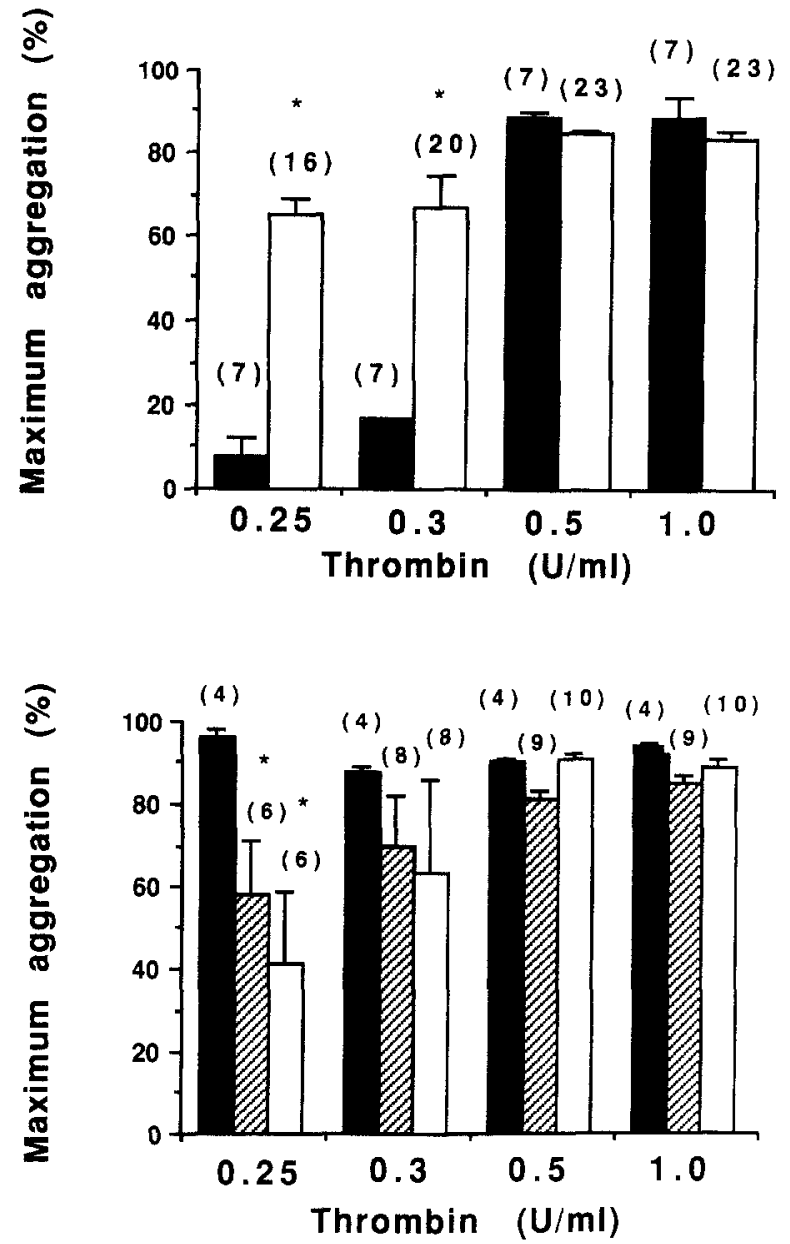

Fig.3. Thrombin-induced maximum platelet aggregation. Maximum platelet aggregation was measured as described in subjects and methods. Upper panel: platelet aggregation rate in diabetic patients $(\square)$ and control subjects ( $\square$ ). Lower panel: indicated platelet aggregation rate in the subjects treated with diet only $(\boldsymbol{\square})$, insulin ( $\bullet$ ) and sulphonylureas ( $\square$ ). Data are expressed as mean \pm SEM of 23 diabetic subjects and 7 control subjects. $* p<0.05$

1 and $10 \mathrm{~min}$. Reaction was terminated by the addition of sample buffer $(150 \mathrm{mmol} / \mathrm{ITris} / \mathrm{HCl}, \mathrm{pH} 6.8,7.5 \% \mathrm{SDS}, 12 \%$ (v/v) glycerol, $4.5 \%$ 2-mercaptoethanol), followed by placing in boiling water for $3 \mathrm{~min}$. Samples were kept overnight at $4^{\circ} \mathrm{C}$, and then subjected to SDS-PA GE using $12.5 \%$ acrylamide separating gels and $4.5 \%$ stacking gels, both containing $0.1 \%$ SDS. The gels were dried and exposed to Kodak X-Omatic film for $72 \mathrm{~h}$ at $-50^{\circ} \mathrm{C}$ to prepare autoradiographs. The intensity of phosphorylated protein was scanned with a laser densitometer (Pharmacia LKB Biotechnology, Tokyo, Japan) to determine the relative value.

Additional laboratory measurements: Fasting blood glucose levels were determined by the glucose-oxidase method, and $\mathrm{HbA}_{1 \mathrm{c}}$ levels were determined by HPLC. Cholesterol and triglycerides were assayed in the Central Biochemical Laboratory of Gifu University Hospital.

\section{Statistical analysis}

Statistical analysis was performed by Student's $t$-test. Statistical significance was defined as $p$ less than 0.05 . 

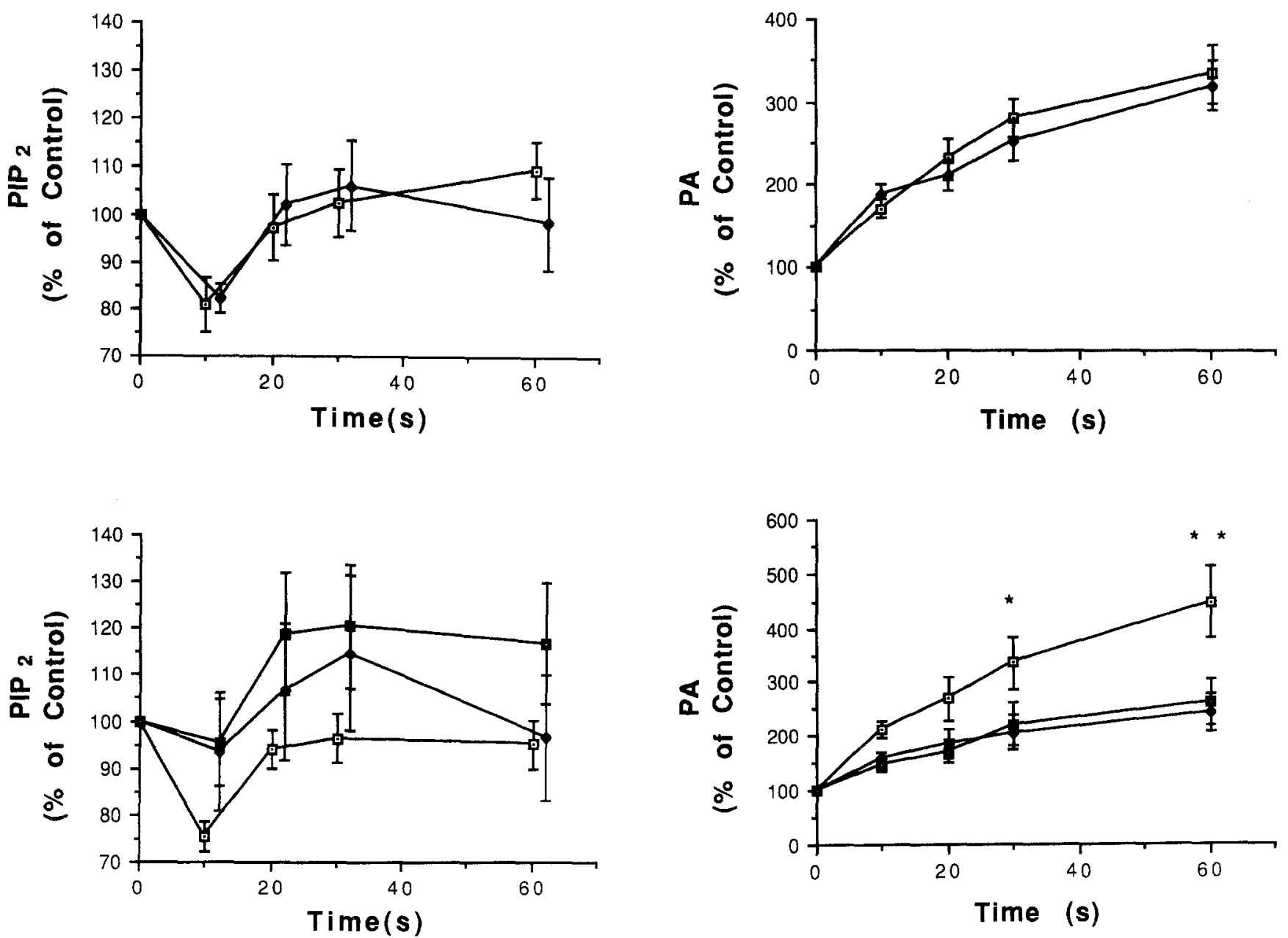

Fig. 4. Thrombin-induced $\mathrm{PIP}_{2}$ change in platelets from diabetic $(\checkmark)$ and control ( $\square$ ) subjects (upper panel), and from diabetic subjects treated by diet only ( $\square)$, sulphonylureas ( $\mathbf{a})$, and insulin $(\bullet)$ (lower panel). Data are expressed as mean \pm SEM of 32 diabetic patients and 12 control subjects

\section{Results}

Platelet aggregation in diabetic subjects: Low-dose $(0.25$ and $0.3 \mathrm{U} / \mathrm{ml})$ thrombin-induced maximum aggregation in diabetic subjects was higher than in control subjects $(0.25 \mathrm{U} / \mathrm{ml}$; diabetic $65 \pm 4 \%$ vs control subjects $8 \pm 4 \%, 0.3 \mathrm{U} / \mathrm{ml}$; diabetic $67 \pm 8 \%$ vs control subjects $17 \pm 5 \%, p<0.01)$. However, higher dose $(0.5$ and $1 \mathrm{U} / \mathrm{ml})$ thrombin-induced maximum aggregation in diabetic subjects was similar to that in the control subjects $(0.5 \mathrm{U} / \mathrm{ml}$; diabetic $85 \pm 2 \%$ vs control subjects $89 \pm 2 \%, 1 \mathrm{U} / \mathrm{ml}$; diabetic $84 \pm 2 \%$ vs control subjects $89 \pm 5 \%$ ) (Fig.3). Diabetic subjects were divided into three groups as indicated in Table 1. Low-dose $(0.25 \mathrm{U} / \mathrm{ml})$ thrombin-induced maximum aggregation in the sulphonylurea group and insulin group was significantly lower than in the diet group $(0.25 \mathrm{U} / \mathrm{ml}$; diet $96 \pm 2 \%$ vs insulin $58 \pm 13 \%$, or sulphonylurea $41 \pm 18 \%, p<0.05$ ) (Fig.3). However, thrombin-induced maximum ag-

Fig.5. Thrombin-induced PA formation in platelets from diabetic ( $)$ and control ( $\square$ ) subjects (upper panel). Thrombininduced PA formation in platelets from diabetic subjects treated by diet only ( $\square$ ), sulphonylureas ( $\square$ ), and insulin $(\bullet)$ (lower panel). Data were expressed as mean \pm SEM of 32 diabetic patients and 12 control subjects. ${ }^{*} p<0.05,{ }^{* *} p<0.01$

gregation in the insulin group was higher than that in control subjects.

Thrombin-induced phosphoinositide metabolism in diabetic and control subjects: As indicated in Figure 2 each phosphoinositide was separated by HPTLC. Radioactivity of $\mathrm{PIP}_{2}$ (TPI:Triphosphoinositide) was rapidly hydrolysed by phospholipase $\mathrm{C}$ within $10 \mathrm{~s}$ (control subjects: $n=12$, stimulation with thrombin for $0[100 \%]$ vs for $10 \mathrm{~s}[80.7 \pm 5.8 \%] p<0.01$; diabetic subjects: $n=31$, stimulation with thrombin for 0 $[100 \%$ ] vs for $10 \mathrm{~s}[82.2 \pm 3.3 \%], p<0.01$, as indicated in Figure 4), and PA was increased by $60 \mathrm{~s}$ after stimulation with thrombin $(1 \mathrm{U} / \mathrm{ml})$ in both control and diabetic subjects. In this case, hydrolysis of $\mathrm{PIP}_{2}$ was increased in each diabetic subject compared to each control subject. Figure 5 shows that percent increases of PA were not significantly different from those in control subjects. However, percent increases of PA radioactivity in the insulin and sulphonylurea groups 

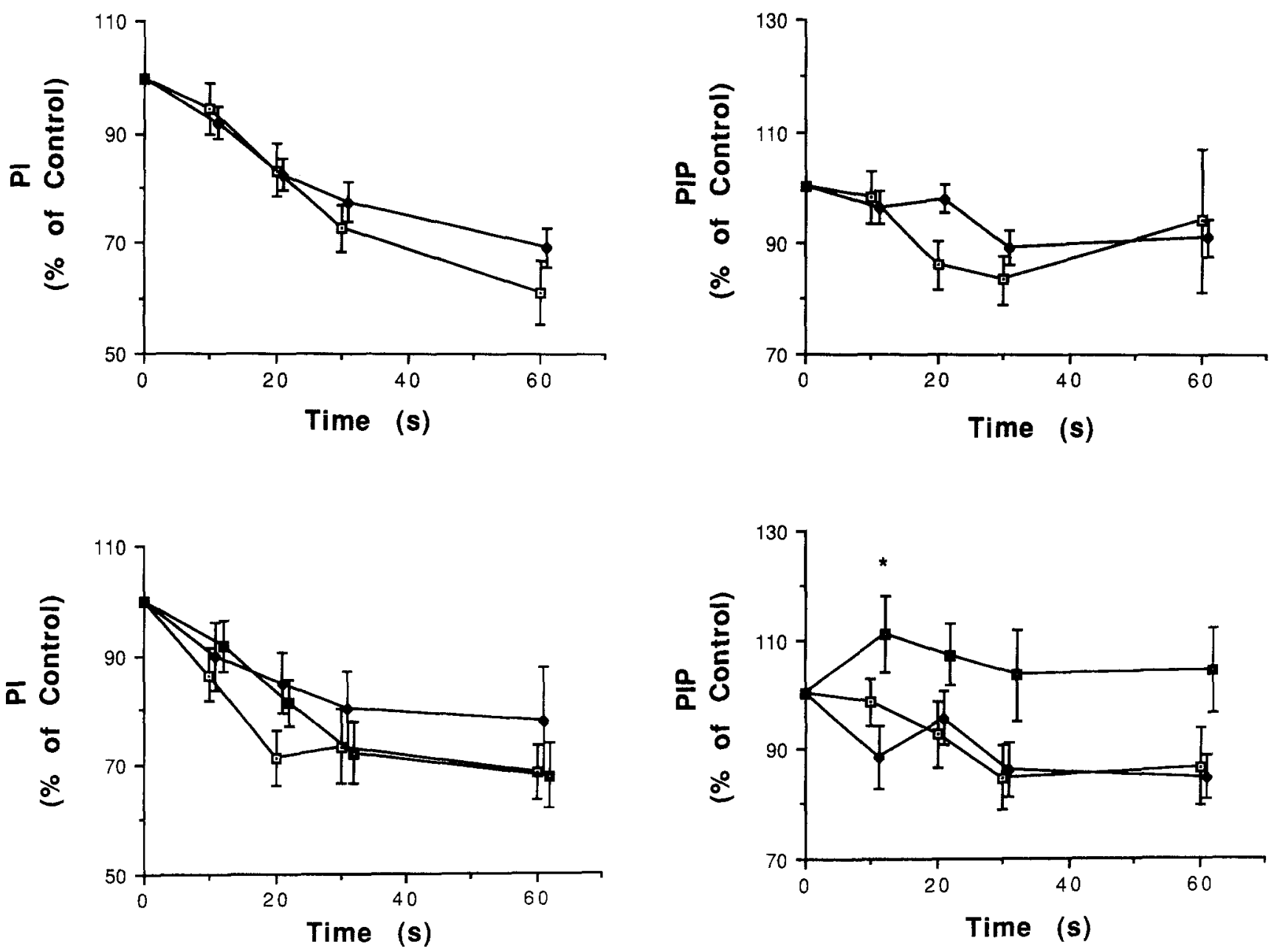

Fig. 6. Thrombin-induced PI change in platelets from diabetic ( $)$ and control ( $\square$ ) subjects (upper panel), and from diabetic subjects treated by diet only $(\ominus)$, sulphonylureas $(\boldsymbol{\square})$, and insulin ( ) (lower panel). Data are expressed as mean \pm SEM of 32 diabetic patients and 12 control subjects

were lower than in the diet group 30 and $60 \mathrm{~s}$ after stimulation with $1 \mathrm{U} / \mathrm{ml}$ thrombin (at $60 \mathrm{~s}$, diet group: $450 \pm 65 \%$ vs sulphonylurea group: $264 \pm 42 \%$ or insulin group: $245 \pm 35 \%, p<0.05-0.01$ ). These results indicated that thrombin-induced phospholipase $\mathrm{C}$ activity in the insulin and sulphonylurea groups was lower than in the diet group. Thrombin-induced changes in each $\mathrm{PIP}_{2}$, PIP (diphosphoinositide:DPI) and PI radioactivity in the diabetic subjects were not significantly different from those in the control subjects. Moreover, there were no significant differences in thrombin-induced changes in $\mathrm{PIP}_{2}$ or PI radioactivity among the sulphonylurea, insulin and diet groups and control subjects (Figs. 4 and 6). However, thrombin-induced PIP hydrolysis in the sulphonylurea group was decreased compared with the diet group (at $10 \mathrm{~s}$, sulphonylurea group: $111 \pm 7 \%$ vs diet group: $99 \pm 4 \%$ ) (Fig. 7). These results indicated that thrombin-induced PIP-specific phospholipase $\mathrm{C}$ activity in the sulphonylurea group was decreased compared to that in the diet

Fig. 7. Thrombin-induced PIP in platelets from diabetic $(\Delta)$ and control ( $\square$ ) subjects (upper panel), and from diabetic subjects treated by diet only ( $\square)$, sulphonylureas $(\mathbf{a})$, and insulin $(\bullet)$ (lower panel). Data are expressed as mean \pm SEM of 32 diabetic patients and 12 control subjects. ${ }^{*} p<0.05$

group. Each thrombin-induced phosphoinositide change (PA, PIP, PI, and PIP) in the diet group was not significantly different from that in control subjects, respectively.

$47 \mathrm{kDa}$ protein phosphorylation in diabetic patients: Thrombin- or TPA-stimulated phosphorylation of $47 \mathrm{kDa}$ protein in diabetic subjects was not significantly different from that in the control subjects (Fig. 8). Moreover, there was no significant difference in thrombin- or TPA-induced $47 \mathrm{kDa}$ protein phosphorylation among platelets from the diet, sulphonylurea insulin groups, respectively (thrombin stimulation at $1 \mathrm{~min}$ : diet $1725 \pm 1067 \% n=6$, insulin $1435 \pm 280 \% n=12$; sulphonylurea $1147 \pm 297 \% n=12$, TPA stimulation at $1 \mathrm{~min}$ : diet $1366 \pm 725 \% n=6$, insulin $1206 \pm 253 \%$ $n=12$; sulphonylurea $1025 \pm 258 \% \quad n=12$; mean \pm SEM, control $100 \%$ ). 


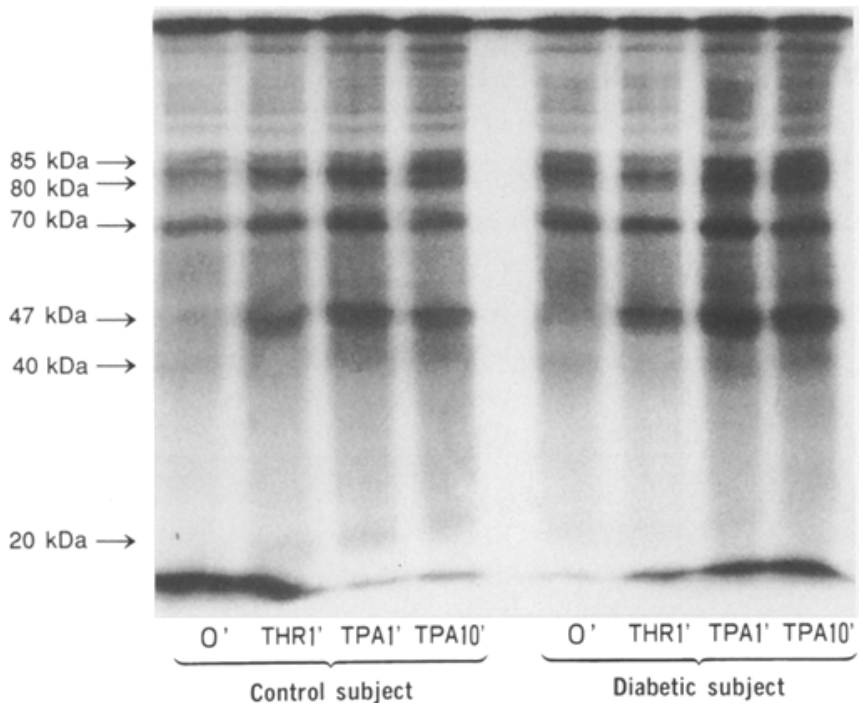

Fig. 8. Studies and platelets phosphorylated by thrombin for $1 \mathrm{~min}$ and TPA for 1 and $10 \mathrm{~min}$ in a diabetic patient (right) and in a control subject (left)

\section{Discussion}

Thrombin-induced phosphoinositide metabolism and subsequent formation of diacylglycerol and protein kinase $\mathrm{C}$ activation are essential signal transduction mechanism(s) linked to platelet aggregation [21-23]. Several studies have been conducted to investigate the mechanism(s) responsible for the enhanced platelet responsiveness to aggregation and release-induced stimuli in both man and animals with diabetes $[9,10]$. Most of these studies have focused on whether the arachidonic acid metabolism of platelets is altered in diabetes $[11,12$, 24]. Recently, the breakdown of phosphoinositides has drawn attention as being the earliest even underlying the reactivity of platelets. Platelet shape change induced by thrombin is closely linked to phosphoinositide hydrolysis and may be independent of the liberation and metabolism of arachidonic acid [25]. We have already reported [15] enhanced hydrolysis of $\mathrm{PIP}_{2}$ by phospholipase $\mathrm{C}$ in platelets from diabetic subjects with microangiopathy as compared with control subjects. However, thrombin-induced phosphoinositide metabolism in platelets from untreated diabetic subjects has not been investigated. Thus, we have aimed to examine whether phosphoinositide metabolism in platelets from diabetic subjects behaves differently according to type of treatment. Moreover, we have shown that there are no significant differences between diet, sulphonylurea, and insulin groups in thrombin-induced $47 \mathrm{kDa}$ protein phosphorylation [26].

Low-dose thrombin-stimulated platelet aggregation in diabetic patients was increased compared to control subjects, indicating that platelets from diabetic patients had been enhanced in thrombin-, ADP-, and collageninduced aggregation, consistent with previous reports of in vivo and in vitro platelet activity [27-31]. Our data also indicate that thrombin-induced platelet aggregation in the insulin or sulphonylurea groups was decreased compared with the diet group. Although thrombin-induced PA formation, which is almost identical to phospholipase Cactivity, in the insulin and sulphonylurea groups was decreased compared with the diet group, no significant differences in thrombin- or TPA-induced $47 \mathrm{kDa}$ protein phosphorylation between platelets from the three groups of diabetic patients were observed. The lack of an exact correlation between thrombin-induced phosphoinositide metabolism and thrombin-induced $47 \mathrm{kDa}$ protein phosphorylation may have been due to the following: first, it may have been the result of influences of thrombin-stimulated phospholipase $\mathrm{A}_{2}$ activation on platelet aggregation and other platelet function(s). Secondly, PA synthesis generated by phospholipase C- and D-mediated hydrolysis of phosphatidylcholine $[32,33]$ and from the de novo pathway [34] may have been too complex. Thirdly, protein kinase $\mathrm{C}$ may have regulated phosphoinositide metabolism and $\mathrm{Ca}^{2+}$ release from intracellular stores [26]; finally, as each diabetic group was complicated with various types and grades of micro- and macroangiopathy, they may have been heterogenous.

These results suggest that sulphonylurea and insulin treatment suppress phospholipase C activity which hydrolyses polyphosphoinositides, generates diacylglycerol and induces PA formation in human platelets, and subsequently decreases platelet aggregation. Finally, we hypothesize that insulin and sulphonylurea treatments may affect phosphoinositide metabolism, protein phosphorylation and platelet aggregation and the development of diabetic complications.

\section{References}

1. Rittenhouse-Simmons S (1979) Production of diglyceride from phosphatidylinositol in activated platelets. J Clin Invest 63:580-587

2. Broekman MJ, Ward JW, Marcus AJ (1980) Phospholipid metabolism in stimulated human platelets. J Clin Invest 66: 275-283

3. Billah MM, Lapetina EG (1982) Rapid decrease of phosphatidylinositol 4,5-bisphosphate in thrombin-stimulated platelets. J Biol Chem 25: 12705-12708

4. Imai A, Nakashima S, Nozawa Y (1983) The rapid polyphosphoinositide mediated stimulation of human platelets. Biochem Biophys Res Commun 110: 108-115

5. Brass LF, Joseph SK (1985) A role of inositol trisphosphate in intracellular $\mathrm{Ca}^{2+}$ mobilization in platelet activation. J Biol Chem 260: 15172-15179

6. Kaibuchi K, Takai Y, Sawamura M, Hoshijima M, Fujikura T, Nishizuka Y (1983) Synergistic functions of protein phosphorylation and calcium mobilization in platelet activation. $J$ Biol Chem 258: 6701-6704

7. Lapetina EG, Reep B, Ganong BR, Bell RM (1985) Exogenous sn-1,2-diacylglycerols containing saturated fatty acids function as bioregulators of protein kinase $\mathrm{C}$ in human platelets. J Biol Chem 260: 1358-1361 
8. Marcus AJ (1978) The role of lipids in platelet function: with particular reference to the arachidonic acid pathway. J Lipid Res 19: 793-826

9. Bern MM (1978) Platelet function in diabetes mellitus. Diabetes 27:342-350

10. Colwell JA, Winocour PD, Lopes-Virella M, Halushka PV (1983) New concepts about the pathogenesis of atherosclerosis in diabetes mellitus. Am J Med 75: 67-80

11. Takahashi R, Morita I, Murota S, Shiraki M, Ito M, Orimo H (1983) Dietary arachidonic acid supplementation increase thromboxane synthesizing activity in platelets from diabetes. Prostaglandins Leukot Med 75: 67-80

12. Takahashi R, Morita I, Saito Y, Ito H, Murato S (1984) Increased arachidonic acid incorporation into platelet phospholipids in type 2 (non-insulin-dependent) diabetes. Diabetologia 26: 134-137

13. Bastyr EJ, Kadrofske MM, Dershimer RC, Vinik AI (1989) Decreased platelet phosphoinositide turnover and enhanced platelet activation in IDDM. Diabetes 38: 1097-1102

14. Ishii H, Umeda F, Hashimoto T, Nawata H(1990) Changes in phosphoinositide turnover, $\mathrm{Ca}^{2+}$ mobilization, and protein phosphorylation in platelets from NIDDM patients. Diabetes 39: 1561-1568

15. Ishizuka T, Yasuda K, Takeda N et al. (1991) Thrombin-induced breakdown of phosphoinositides in platelets from patients with NIDDM. Endocrinol Japon 38: 81-87

16. Chimori K, Miyazaki S, Kosaka J, Sakanaka A, Yasuda K, Miura K (1987) The significance of autonomic neuropathy in the elevation of inactive renin in diabetes mellitus. Clin Exp Hypertens [A] 9: 19-32

17. Marche P, Koutouzov S, Meyer P (1982) Metabolism of phosphoinositides in the rat erythrocyte membrane. A reapraisal of the effect of magnesium on the ${ }^{32} \mathrm{P}$ incorporation into phosphoinositides. Biochem Biophys Acta 710: 332-340

18. Bligh EG, Dyer WJ (1959) Rapid method of total lipid extraction and purification. Can J Biochem Physiol 37: 911-917

19. Jolles J, Schrama LH, Gispen WJ (1981) Calcium-dependent turnover of brain polyphosphoinositides in vitro after prelabelling in vivo. Biochem Biophys Acta 666: 90-98

20. Born GVT (1962) Aggregation of blood platelets by adenosine diphosphate and its reversal. Nature 194: 927-929

21. Huang EM, Detwiller TC (1987) Thrombin induced phosphoinositide hydrolysis in platelets: receptor occupancy and desensitization. Biochem J 242: 11-18

22. Verhoeven AJM, Gorter G, Mommersteeg ME, Akkerman JWN (1985) The energetics of platelet responses: energy consumption during shape change and aggregation with special reference to protein phosphorylation and the phosphoinositide cycle. Biochem J 228: 451-462
23. Holmsen H, Dangelmaier CA, Rongved S (1984) Tight coupling of thrombin-induced acid hydrolase secretion and phosphatidate synthesis to receptor occupancy in human platelets. Biochem J 222: 157-167

24. Kalofoutis A, Lekakis J (1981) Change of platelet phospholipids in diabetes mellitus. Diabetologia 21:540-543

25. Siess W, Weber PC, Lapetina EG (1984) Activation of phospholipase $\mathrm{C}$ is dissociated from arachidonate metabolism during platelet shape change induced by thrombin or platelet-activating factor. J Biol Chem 259: 8286-8292

26. Tyers M, Rachubinski RA, Stewart MI et al. (1988) Molecular cloning and expression of protein kinase $\mathrm{C}$ substrate of platelets. Nature 333: 470-473

27. Burrows AW, Chavin SI, Hockaday TDR (1978) Plasmathromboglobulin concentrations in diabetes mellitus. Lancet I: 235-237

28. Preston FE, Ward JD, Marcola BH, Porter NR, Timperley WR (1978) Elevated $\beta$-thromboglobulin levels and circulating platelet aggregates in diabetic microangiopathy. Lancet I: 238-239

29. Borsey DQ, Dawes J, Fraser DM, Prowse CV, Elton RA, Clarke BF (1980) Plasma beta-thromboglobulin in diabetes mellitus. Diabetologia 18: 353-357

30. Segel J, Colwell JA, Crook L, Laimins M (1975) Increased platelet aggregation in early diabetes mellitus. Ann Intern Med 82: 733-738

31. Bensoussan D, Levy-Toledano S, Possa P, Caen J, Canivet J (1975) Platelet hyperaggregation and increased plasma level of von Willebrand factor in diabetics with retinopathy. Diabetologia 11: 307-312

32. Besterman JM, Duronio V, Cuatrecasas P (1986) Rapid formation of diacylglycerol from phosphatidylcholine: a pathway for generation of a second messenger. Proc Natl Acad Sci USA 83: 6785-6789

33. Bocckino SB, Blackmore PF, Wilson PB, Exton JH (1987) Phosphatidate accumulation in hormone-treated hepatocytes via a phospholipase D mechanism. J Biol Chem 262: $15309-15315$

34. Farese RV, Konda TS, Davis JS, Standaert ML, Pollet RJ, Cooper DR (1987) Insulin rapidly increases diacylglycerol by activating de novo phosphatidic acid synthesis. Science 236: $586-589$ 